\title{
EVALUATION OF AN UPPER CRETACEOUS LIMESTONE FROM THE AREA OF ARTA FOR LIME PRODUCTION G. CHRISTIDIS ${ }^{1}$ G. TRIANTAFYLLOU ${ }^{1}$ AND T. MARKOPOULOS ${ }^{1}$
}

\section{ABSTRACT}

Calcination of an Upper Cretaceous limestone from the Ionian Unit at $700-1100^{\circ} \mathrm{C}$ for $1-4$ hours yielded very reactive lime end products. Lime formation was monitored by means of kinetic curves and TTT diagrams. Particle size seems to control the onset of lime crystallization at low temperatures, but is of minor importance at higher temperatures. With the experimental setting used, lime formation was completed at $900^{\circ} \mathrm{C}$. The specific surface area of the end products increases with firing temperature up to $800^{\circ} \mathrm{C}$, decreasing thereafter. Decrepitation of lime increases gradually with firing temperature. Hydration temperature during slaking increases rapidly up to $900^{\circ} \mathrm{C}$ being relatively constant thereafter. Sintering and production of fines during firing control the physical properties of lime.

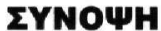

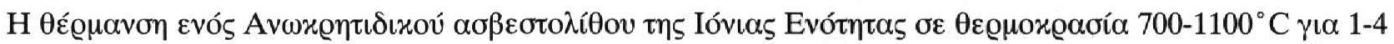


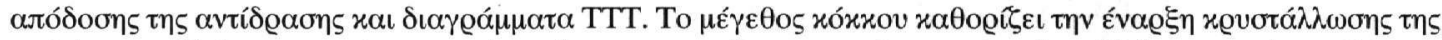

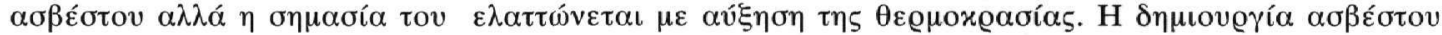

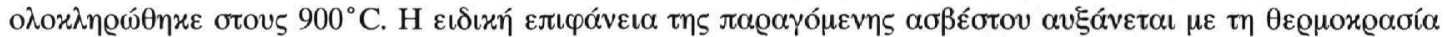

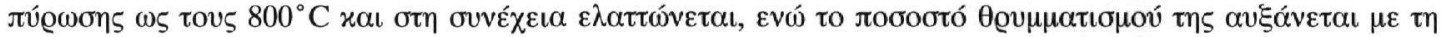

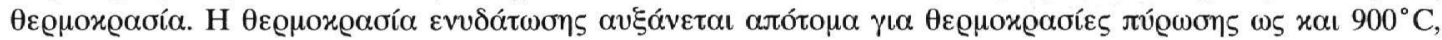

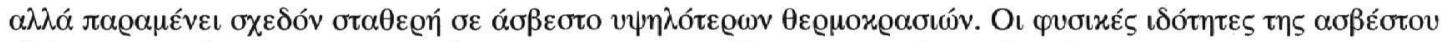

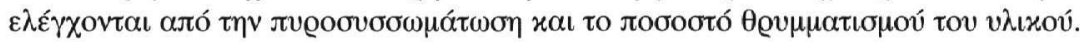

KEY WORDS: limestone, lime, TTT-diagrams, reaction kinetics, specific surface area, decepitation, slaking, sintering.

\section{INTRODUCTION}

Limestones are among the most widespread and the widely utilized mineral commodities in world scale. In general, carbonate rocks occupy about $15 \%$ of the sedimentary crust (Carr et al. 1994). They are used as aggregates, fluxes, glass raw materials, Portland cement raw materials, fillers, reactive agents in sulphur-oxide removal, abrasives, soil conditioners, ingredients in a host of chemical processes, in lime production etc. Although its use goes back before recorded history new uses and products are continually being found.

Lime is the calcined or burned form of limestone, commonly known as quicklime, calcium oxide, or when water is added, calcium hydroxide or slaked lime. The mineral with formula $\mathrm{Ca}(\mathrm{OH})_{2}$ is known as portlandite. For the production of good quality of lime high calcium or high magnesium limestone is preferred. Lime is a very important industrial commodity and it is used in the construction industry, as metallurgical flux, in chemical industry, in the production of sugar, glass, paper, in various agricultural applications etc (Boynton, 1980).

Greece is a country particularly endowed in limestone reserves, since the vast majority of the External Hellenides is composed of carbonates, both limestones and dolomite. Various types of carbonates including marbles from several areas of the country are suitable for production of fillers (Kaliambakos \& Panagopoulos 1994, Lazaridis, 1994, Hatzilazaridou et al. 1998, Repouskou et al. 1999) and aggregates (Repouskou et al., 1999). With limited exceptions (eg. Kantiranis et al. 2000) lime production from limestones has been studied less extensively. The purpose of this contribution is to evaluate the suitability of a Cretaceous limestone from Ionian geotectonic unit for lime production, to examine some important properties of the end product and to propose a method for evaluation of the optimum time and temperature for lime formation.

1. Technical University of Crete, Department of Mineral Resources Engineering, 73100 Chania. 


\section{GEOLOGY}

The limestone samples were collected from the Kampi Area N-NW of Arta town (Fig. 1), from a licensed limestone quarry operated by Kampi Quarries S.A. The limestone is used exclusively as concrete aggregate and roadstone. The material is an Upper Senonian, almost horizontal in general pelagic limestone, striking NNESSW, which belongs to the Ionian Geotectonic Unit. In places, especially in the upper sections of the deposit, the limestone is intensively folded. In the lower stratigraphic horizons the deposit is thick-bedded (bed thickness up to $6 \mathrm{~m}$ ), and has brecciated texture. The thick limestone beds are separated by $c a .30 \mathrm{~cm}$ thick intercalations of sub-lithographic material with Globotruncanidae fossils (Monopolis 1969). The proportion of thin-bedded material increases upwards, and in the uppermost sections of the deposit the limestone is exclusively thin bedded. Throughout the quarry face limestone beds of gray to pale red colour are present. Moreover, $2-5 \mathrm{~cm}$ (rarely up to $30 \mathrm{~cm}$ ) thick flint lenses are ubiquitous throughout the quarry face. The flint lenses constitute about $1 \%$ of the total volume of the deposit and its presence adversely affects extraction and processing of the material. For this reason, the flinty material from the thicker horizons is separated and removed after blasting.

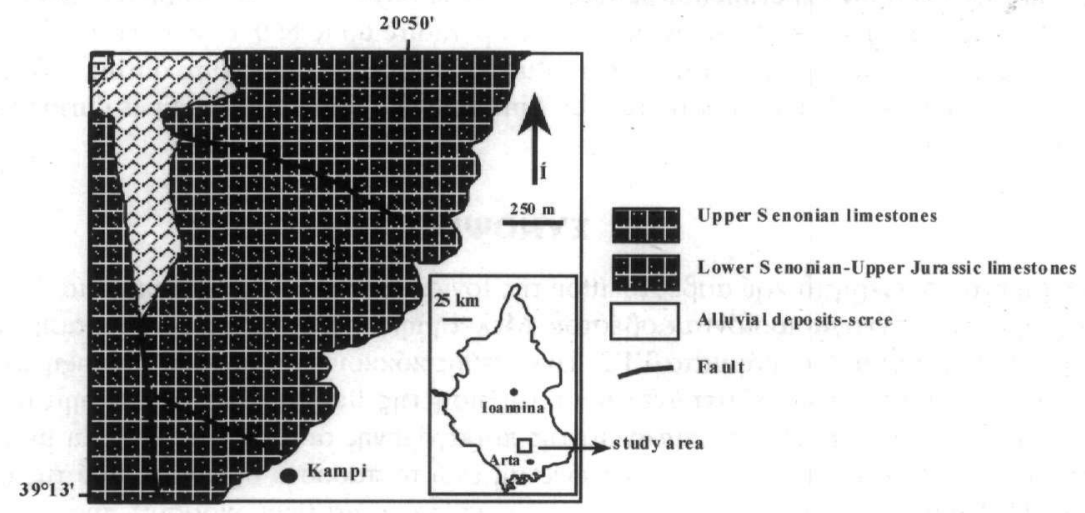

Figure 1. Location and geological map of the study area (modified from IGME, map, Arta sheet, 1969). $L=$ quarry.

\section{MATERIALS AND METHODS}

Representative samples were collected from the quarry face, in order to study the different types of the carbonate rocks in detail. The mineralogy of the materials was determined with optical microscopy and x-ray diffraction (XRD), using a Siemens D500 x-ray diffractometer, (CuK $\alpha$ radiation, graphite monochromator), operating at $35 \mathrm{kV}$ and $40 \mathrm{~mA}$. The calcite content was determined using a Dietrich-Fruhling calcimeter, by calculating the amount of carbon dioxide given off, and converting it to $\mathrm{CaCO}_{3}$. Measurements were controlled by means of a well characterized limestone standard containing $99.01 \%$ calcite and having $43.56 \% \mathrm{CO}_{2}$ content. The combination of XRD and the calcimeter assisted the detection of possible traces of dolomite and the assignment of the $\mathrm{CO}_{2}$ content accordingly.

Evaluation of the limestone for production of lime was made using a $30 \mathrm{~kg}$ homogenized sample, which is sold as aggregates, collected from a stockpile. This is considered a representative industrial sample, which contains all possible varieties of the carbonate material present in the deposit, and which are most likely to be used as kiln feed in lime manufacture. Macroscopic evaluation of the collected material showed that flint pebbles were not present. In order to study the kinetics of the reaction, two types of materials were prepared: a coarsergrained material 10-2 mm, and a fine-grained material less than $150 \mu \mathrm{m}$. Although both sizes are considerably finer compared to the grain size traditionally employed by the Greek industry, there certain types of kilns, like the fluidized bed kiln, which accept sizes finer than the coarser material used in this study. Both materials were fired at temperatures $700-1100^{\circ} \mathrm{C}$ for $1-4$ hours.

The progress of the reaction was monitored by means of the loss of ignition, using the ratio $\mathrm{C} / \mathrm{Co}$, whereby $\mathrm{C}$ is the weight loss during firing at any temperature and Co the weight loss at $1100^{\circ} \mathrm{C}$ and 4 hours treating time. The heated samples were examined with XRD and the results were used for the construction of Time-Temperature-Transformation (TTT) diagrams. TTT diagrams represent the overall rate of transformation of a mineral phase and describe the transformation of a phase in a time-temperature diagram (Putnis \& McConnel 1980). An 
important outcome of TTT diagrams is the determination of the minimum temperature and time necessary for the synthesis of a mineral, with simultaneous energy conservation during firing (Manning, 1995).

The quality of lime produced from the coarser-grained materials at firing cycles of 1 and 4 hours at temperatures $800-1100^{\circ} \mathrm{C}$ was evaluated by means of BET surface area, degree of decrepitation (formation of finegrained material from desintegration during firing), hydration temperature during slaking according to ASTM C110, and examination with SEM (JEOL JSM 5400). These tests were carried out on samples, which were totally converted to lime. BET surface area was measured with a NOVA 2200 (Quantachrome) BET analyzer, using $\mathrm{N}_{2}$ as adsorbent gas. Before surface area determination, the samples were degassed overnight at $140^{\circ} \mathrm{C}$. Before each test lime was kept in sealed desiccators due to its tendency to adsorb moisture.

\section{RESULTS}

\section{Raw materials and firing results}

The raw material is a very compact micritic limestone rich in microfossils (foraminifera) with occasional sparitic cement. One sample (A2) is a pink limestone containing small amounts of Fe-oxides, while the remaining samples are off-white materials containing trace amounts of quartz. Dolomite was not detected. The calcite content of the various representative samples and the stockpile and the results from determination of loss of ignition (LOI) are listed in Table 1. It is obvious that all samples except A2 are ultra high purity limestones (calcite content $>99 \%$ ), while A2 is a high purity limestone. In accordance with these results, LOI values approach that of pure calcite (44\%). Again A2 has slightly lower LOI than the remaining samples.

\section{Table 1}

Calcite contents determined from the calcimeter and $L O I$ of all representative limestones collected from the quarry face $(A 1, A 2, A 4, A 5)$ and the stockpile $(A 3)$. UHPL = ultra high-purity limestone, VHPL $=$ very highpurity limestone.

\begin{tabular}{|c|c|c|c|c|}
\hline Sample & ㅇ $\mathrm{CO}_{2}$ in limestone & $\begin{array}{l}\text { Calcite } \\
(\%)\end{array}$ & $\begin{array}{c}\text { content LOI of } \\
\left(\frac{\circ}{\%}\right)\end{array}$ & limestone \\
\hline A1 & 43.67 & 99.3 (UHPL) & 43.62 & \\
\hline $\mathrm{A} 2$ & 43.28 & 98.4 (VHPL) & 43.40 & \\
\hline A3 & 43.63 & 99.2 (UHPL) & 43.71 & \\
\hline A4 & 43.85 & 99.7 (UHPL) & 43.88 & \\
\hline A5 & 43.71 & 99.4 (UHPL) & 43.78 & \\
\hline
\end{tabular}

The curves describing the kinetics of the conversion of limestone to lime for the fine and the coarse-grained samples are shown in Figure 2. As expected, the fine-grained sample displays a higher conversion rate. This is observed clearly at $800^{\circ} \mathrm{C}$ whereby the slope of the curve for the fine-grained material is greater compared to the coarse-grained. At higher temperatures the role of grain-size does not seem to be very important. Also it is obvious that the fine-grained material is more reactive even at $700^{\circ} \mathrm{C}$, at long heating cycles.
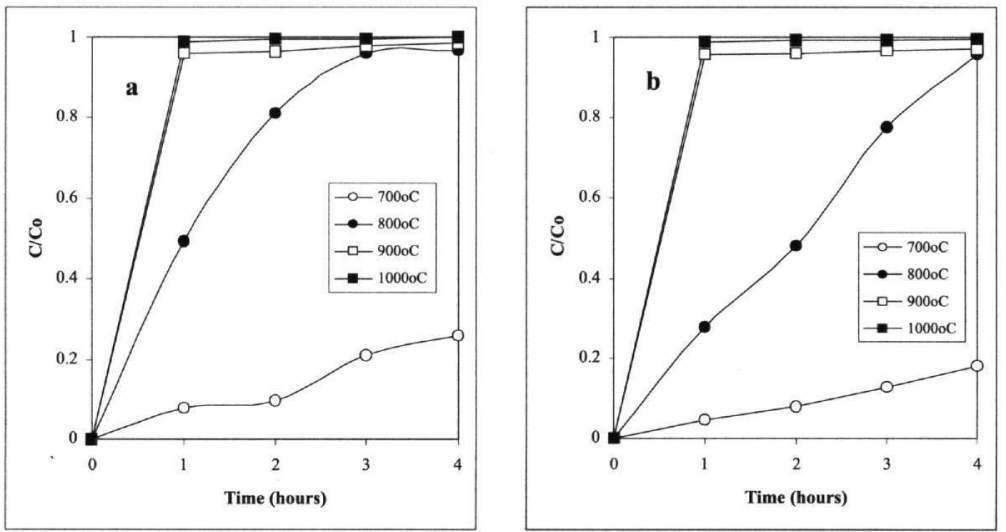

Figure 2. Kinetic curves for lime production. a) Fine-grained material b) coarse-grained material 
The TTT diagrams for the fine- and the coarser-grained samples, which display the whole range of transformations from calcite to lime during firing, are shown in Figure 3. The diagrams confirm that the starting temperature for conversion of calcite (Tc) is lower for the fine-grained-compared to the coarse-grained material $\left(700^{\circ} \mathrm{C}\right.$ and $800^{\circ} \mathrm{C}$ respectively). In contrast the temperature for complete transformation to lime ( $\left.\mathrm{Tc}^{\prime}\right)$ is common for both materials. Therefore, the data in Figures 2 and 3 suggest that grain size affects only the starting temperature of transformation to lime, not the temperature of complete transformation.
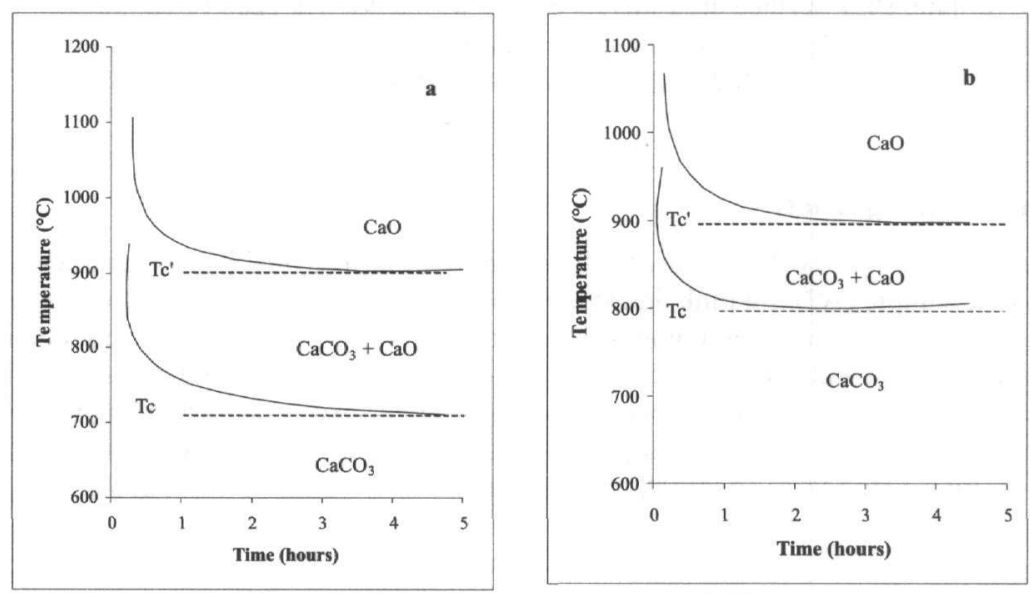

Figure 3. Time-temperature-transformation (TTT) diagrams of lime formation, a) Fine-grained material b) coarse-grained material

\section{Evaluation of lime products}

In general, the end products produced from the various firing cycles exhibited rapid hydration even when lime was kept in desiccators. Even a short exposure to atmospheric conditions resulted to the formation of portlandite. Also the firing colour of the lime products was white, although the colour of the raw materials varied according to the chemical and mineralogical composition.

The results from BET specific surface area measurements for the short (1 hour) and long (4 hours) firing cycles are shown in Figure 4. In both cases specific surface area increases to a maximum decreasing gradually thereafter. Also for both firing cycles maximum specific surface area is observed at $800^{\circ} \mathrm{C}$. At higher temperatures specific surface area decreases rapidly and the values obtained for the two firing cycles converge gradually. Therefore with increasing temperature reactivity of lime decreases as expected (Scott et al. 1983).

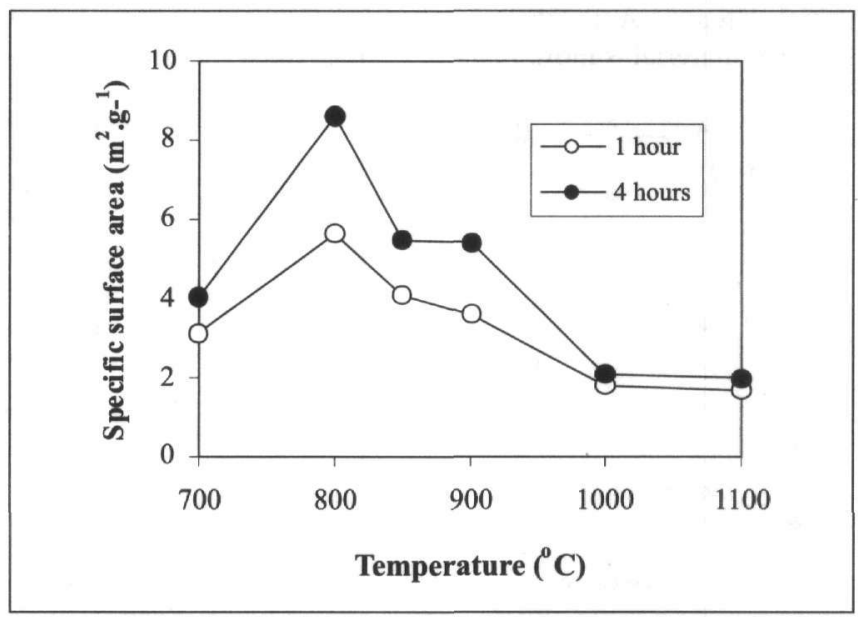

Figure 4. Evolution of the specific surface area of the various lime products produced at different temperatures. 
The results from decrepitation experiments are shown in Figure 5. In both the short and the long firing cycles the amount of fine-grained material produced during firing increased with increasing time of calcinations. The long firing cycles produced greater amount of fines. The slaking experiments (ASTM C 110) showed that hydration proceeds very rapidly (Fig. 6). The material is characterized as a very reactive limestone since hydration is completed within a few minutes. Maximum hydration temperature increases slightly for materials fired above $900^{\circ} \mathrm{C}$. Also the hydration temperatures for the different firing cycles tend to converge to a single value with increasing temperature.

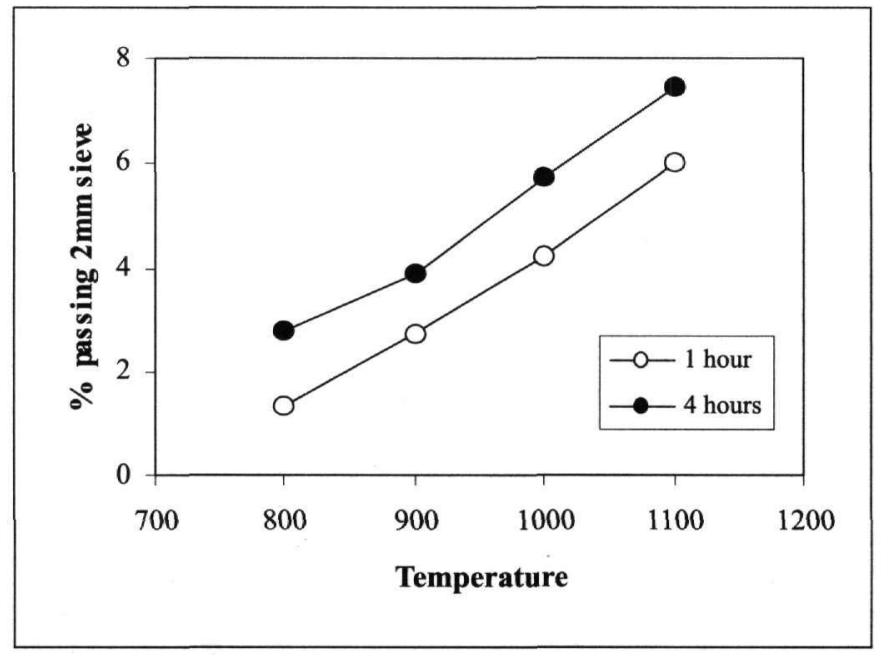

Figure 5. Decrepitation of the lime produced from firing of the Kampi limestone at different temperatures

Representative SEM micrographs of various firing products are shown in Figure 7. Sintering of lime grains is obvious and the appearance of menisci connecting rounded grains is evident. The isometric shape of the individual lime grains is explained, since $\mathrm{CaO}$ crystals are cubic. Hydrated lime grains occur in the form of hairlike crystallites at the end of lime crystals and amorphous material occurs in the form of large spherical clusters, frequently displaying cracks, resembling deccication structures. A gradual increase of the lime grain-size with increase firing temperature is present. The greater crystal size is attributed both to sintering and to crystal growth and is fully compatible with the observed decrease of specific surface area.

\section{DISCUSSION}

Calcination of an ultra-high purity Upper Cretaceous micritic limestone from the Ionian geotectonic unit produced a very reactive lime. The role of the particle size of the feeding material on the reaction rate of lime crystallization seems to be important at the onset of the reaction. In contrast it is of minor importance at higher temperatures, since the kinetic curves of the fine- and the coarse-grained material are almost identical. The main difference between the different grain-sizes was observed at $800^{\circ} \mathrm{C}$ (Fig. 2). At this temperature the coarsegrained material begins to react, while its fine-grained counterpart is more reactive (Fig. 3). Also, at $700^{\circ} \mathrm{C}$ the coarse grained material displays $\mathrm{CO}_{2}$ loss, although crystallization of lime was not observed. The $\mathrm{CO}_{2}$ loss is attributed to the formation of an intermediate, probably amorphous phase, which acts as precursor for lime crystals. At the same temperature the kinetic curve of the fine-grained material displays a step at $3 \mathrm{~h}$ and $4 \mathrm{~h}$ treatments (at ca. 20\% CO2 loss), reflecting the first formation of lime crystals (Fig. 3). This step suggests the existence of an energy barrier, which has to be overcome for the first lime crystals to form. The rather high reactivity of the starting material as indicated by the low temperature of lime formation, is attributed to the micritic nature of the limestone. 

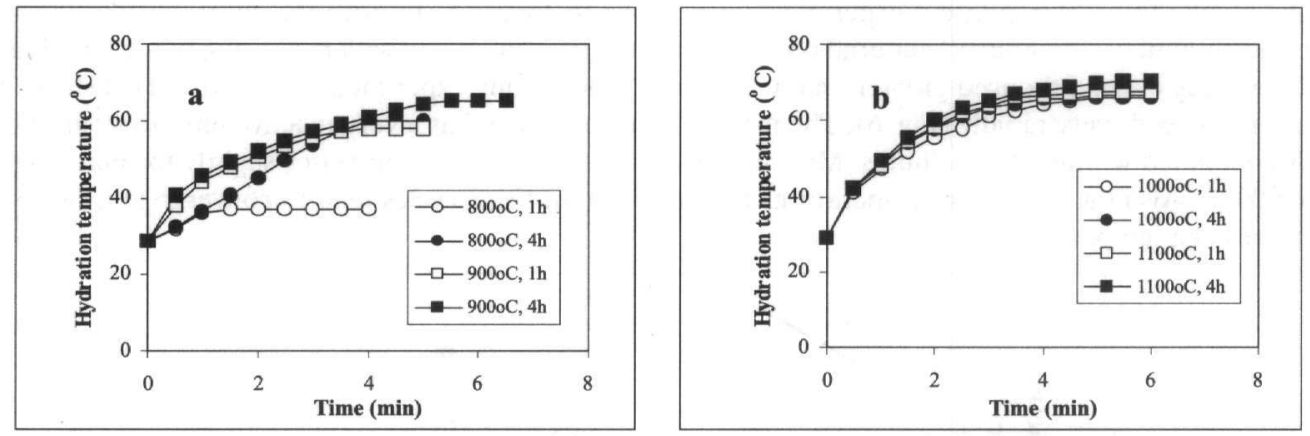

Figure 6. Hydration temperatures developed during slaking of the lime, a) 800 and $900^{\circ} \mathrm{C}$, b) 1000 and $1100^{\circ} \mathrm{C}$.
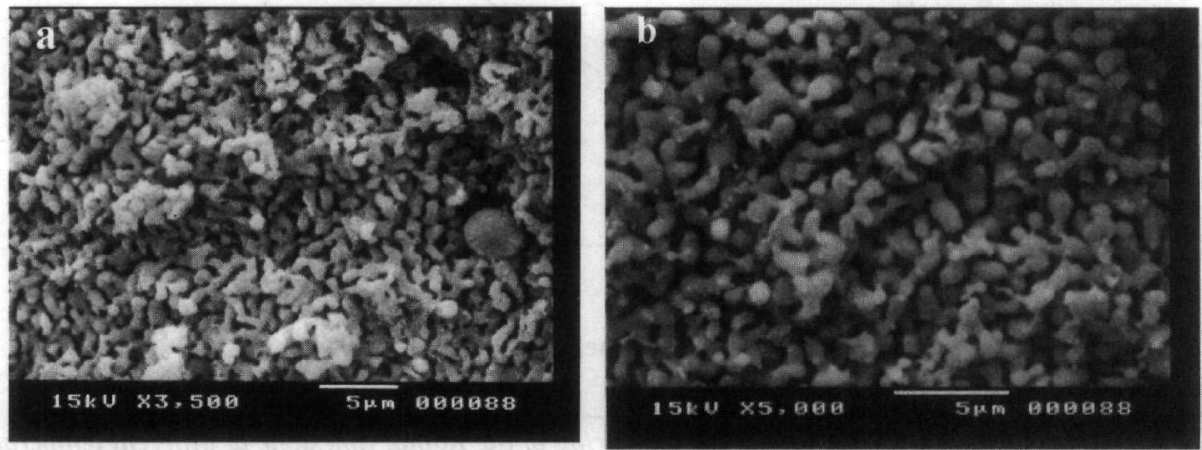

Figure 7. SEM micrographs of lime produced at a) $900^{\circ} \mathrm{C}, 1 \mathrm{~h}$ and b) $1000^{\circ} \mathrm{C}$, $4 \mathrm{~h}$. The spherical particle in the right part of photograph a) belongs to amorphous material.

The specific surface area (SSA) of the end products increases gradually up to a maximum value, decreasing thereafter (Fig. 4). This is a well-known trend observed during lime formation (eg Scott et al. 1983). The decrease of SSA at temperatures higher than $800 \mathrm{CO}_{2}$ is due to the sintering of lime crystals observed in the SEM (Fig. 7). Also the lower maximum value observed for the short firing cycle is attributed to the incomplete transformation of calcite crystals (cf. Fig. 2,3). Finally, the SSA values determined for materials fired at $700^{\circ} \mathrm{C}$, which are too high for limestones, are compatible with the existence of a highly reactive phase. However such a phase was not detected by XRD. Therefore, the suggestion for the existence of a precursor amorphous phase for lime crystals is fully justified.

The slaking tests indicate that the lime produced is very reactive. Also, the hydration temperature measured is high. However, although the SSA decreases with increasing temperature, at temperatures higher than $800^{\circ} \mathrm{C}$ hydration temperature does not decrease. This is attributed to the production of greater amounts of fine material with increasing temperature, due to decrepitation (Fig. 5). The existence of greater amounts of fine material probably attenuates the effect of sintering, which decreases the SSA of lime (Fig. 4) and hence reactivity.

The results obtained showed that the TTT diagrams combined with the kinetic curves are useful tools to determine the optimum conditions for lime production. For the particle size used $(2-10 \mathrm{~mm})$, optimum firing conditions for complete conversion of the Kampi limestone to lime are temperature $900^{\circ} \mathrm{C}$ and $3-4$ hours treating time. For greater particle sizes, which are preferred by the Greek industry, it is expected that higher temperatures might be necessary. We are currently working in this direction. In any case firing tests should be followed by specific tests, such as determination of slaking temperature and the behaviour during decrepitation, for evaluation of the produced lime.

\section{REFERENCES}

BOYNTON, R.S. (1980) Chemistry and technology of lime and limestone. Wiley Interscience N.Y. 534 pp.

CARR, D.D., ROONEY L.F. \& FREAS, R.C. (1994) Limestone and dolomite. In: Industrial Minerals and Rocks

(D.D. Carr ed). AIME Soc. Pp 605-629.

HATZILAZARIDOU, K., CHALKIOPOULOU F. \& GROSSOU-VALTA, M. (1998) Greek Industrial Minerals. 
Current status and trends. Ind. Miner. 369, 45-63.

KANTIRANIS, N. FILLIPIDIS, A, TSIRAMBIDIS, A., CHRISTARAS, V., \& KASOLI-FOURNARAKI, A. (2000) Çégh-Ca quick lime and hydrated lime of the limestone from Agios Panteleimonas Florina for use in water processing. Proc. $1^{\text {st }}$ Conference of the Commission of Economic Geology Mineralogy and Geochemistry Kozani, 177-183 (in Greek).

KALIAMBAKOS, D. \& PANAGOPOULOS K. (1995) Applicability of the dolomitic marble waste of Thassos Island as filler for limiting the relative harmful environmental impacts. Ind. Miner. 333, 29-37.

LASKARIDIS K. (1994) Greek white calcitic marbles examination and appraisal for industry. Ind. Miner. 319, 53-57.

MANNING, D.A.C. (1995) Introduction to industrial minerals. Chapman \& Hall, London, 276 pp.

MONOPOLIS, D. (1969) Geological Map of Greece. Arta Sheet.

PUTNIS, A. \& MCCONNELL, J.D.C. (1980) Principles of Mineral Behaviour. Elsevier N. York. 257 pp.

REPOUSKOU, E. CHRISTIDIS, G., MARKOPOULOS TH. \& SKARPELIS, N. (1999) Geology, physical and chemical properties of carbonate rocks from Crete, Greece. In: C.J. Stanley et al eds): Mineral deposits: Processes to Processing. A.A. Balkema, Rotterdam, 1141-1144.

SCOTT, P.W., THANOON, TH. \& ARODIOGBU, C.O.F. (1983) Evaluation of limestone and dolomite deposits. In: Atkinson K. \& Brassington, R. eds) Prospecting and evaluation of non metallic rocks and minerals. Institution of Geologists, London. 107-126. 